\title{
МОТИВ (БЕЗ)ДОМНОСТІ В РОМАНІ СЕРГІЯ ЖАДАНА «ІНТЕРНАТ»
}

\author{
Уляна ФЕДОРІВ
}

Кандидат філологічних наук, доцент, Львівський національний університет імені Івана Франка, Україна

\section{DOI 10.25128/2304-1222.19.49.03}

The article analyzes the image of the Lost Home in novel «Intemat» by Serhii Zhadan. It is emphasized that Home is one of the dominant images in the writer's creative work, which is realized on various text levels. Chains of symbols are concentrated around it, and well-composed ranks of associations line up around it.

The article draws attention to the fact that the motif of homelessness characteristics of S. Zhadan's creativity is interpreted as a pai nful but extremely necessary stage in the formation of heroes. Attention is drawn to the fact that the author uses the traditional motif of the road, appealing to thetopic of farewell to his homeand the possible (non) returning (to) the Home Serhii Zhadan focuses on the problem of irrational ity and "disorientation on the ground", a double trauma to the totalitarian past and militaristic today. The important aspect in this case is the shaping of new vision of mental home in the society's consciousness which is still in the permanent process of rebuilding its national identity and cultural memory.

Home acts as a spatial metaphor for family memory. Interpreting the Home as a philosophical and ontological constant, the author addresses the problem of internal homelessness, existential orphanhood and conscious spiritual separation from the nativeland.

It is indicated that the traumatic events in the novel are referred through the topos of the non-Home In this context, it is important to anal yze such loci in the novel as a boarding school, a train station, a motel, a checkpoint, and so on.

Key words: topos, Lost Home, non-Home, motif of the road, non-place.

У статті проаналізовано образ Втраченого Дому в романі Сергія Жадана «Інтернат». Звернено увагу на те, що автор використовує традиційний мотив дороги, апелюючи до теми прощання з рідним домом та можливого (не)повернення (до)Дому. У цьому контексті важливим $є$ аналіз таких локусів, як інтернат, вокзал, мотель, магістраль, блокпост тощо.

Дім постає як просторова метафора родинної пам'яті. Сергій Жадан акцентує на проблемі невгрунтованості та «дезорієнтації на місцевості», подвійному травмуванні тоталітарним минулим та мілітарним сьогоднішнім. Відтак наголошено на проблемі ідентичності, самоусвідомлення, його втрати та пошуку. Тлумачачи Дім як філософсько-онтологічну константу, Сергій Жадан звертається до проблеми внутрішньої бездомності та екзистенційного сирітства. Аналізуючи травмоландшафт Донбасу, письменник ретельно вибудовує шлях до Дому як єдино можливий варіант повернення внутрішньої цілісності героїв, як можливість усвідомлення своєї ролі у макросвіті Великого Дому та шанс попрощатися із інтернатом як символічним простором внутрішньої колонії.

Ключові слова: топос, Втрачений Дім, не-Дім, мотив дороги, не-місия. 
W artykule przeanalizowano wizerunek Utraconego Domu w powieści Serhija Żadana „Internat”. Zwraca się uwagę na fakt, że autor wykorzystuje tradycyjny motyw drogi, odwołując się do tematu pożegnania $z$ domem rodzinnym i ewentual nego (nie)powrotu (do) Domu. W tymkontekście ważne jest przeanalizowanie takich pojęć locusowych, jak internat, dworzec, motel, magistrala, blockpost itp.

Dompojawia się jako metafora przestrzenna pamięci rodzinnej. Serhij Żadan podkreśla problem bezpodstawności i „utraty orientacji w miejscowości”, podwójnej traumy spowodowanej totalitarną przeszłością i militarystyczną teraźniejszością. Znakiem tego podkreśla się problem tożsamości, samoświadomości, ję utraty i poszukiwań. Interpretując Dom jako konstantę filozoficzno-ontologiczną, Serhij Żadan odwołuje się do problemu wewnętrznej bezdomności i egzystencjalnego sieroctwa. Analizując kra jobraz Donbasu, pisarz dokładnie buduję drogę do Domu jako jedyny możliwy sposób przywrócenia wewnętrznej integralności bohaterów, jako okazję do uświadomienia własnej roli w makroświecie Wielkiego Domu i szansę pożegnania z internatem jako symboliczną przestrzenią wewnętrznej kolonii.

Słowa kluczowe: topos, Utracony Dom nie-Dom motyw drogi, niemiejsca.

Усе частіше в сучасному літературознавстві дослідники звертаються до вивчення проблеми функціонування топосу Дому в художній літературі. Це і не дивно, адже Дім є одним із найцікавіших базових образів у світовій культурі. Це полісемантичний знак-код, у якому переплітаються буденне та сакральне, загальне та інтимне, універсальне та національно-ментальне: «Дім відноситься до числа основоположних, всеохопних архетипічних образів-концептів, що з прадавніх віків функціонують в людській свідомості. На відміну від первісних архетипів - явищ природи, дім - поняття культурне, продукт людських рук і фантазії» [Кочерга 2008: 115]. Традиційно дім тлумачать як простір, де людина почуває себе захищеною та потрібною. Це своєрідний мікрокосм та вихідна точка, з якої починається дорога людини у глобальний світ, який можна назвати Великим Домом [Элиаде 1987: 219].

«Мені цікаво писати про людину в транзитному стані, в стані підвішеності, комунікативної та побутової відкритості. Дорога передбачає подібну відкритість 3 огляду на власну тимчасовість» - в одному із своїх інтерв’ю зазначив Сергій Жадан [Гриценко]. Його творчість - благодатний грунт для дослідження топосу Дому та мотиву (без)домності, що проявляється на різних текстових рівнях та в різних художніх проекціях. Цій проблемі присвячено уже низка розвідок (дослідження Т. Гундорової [Гундорова 2012, Гундорова 2013], А. Демченко [Демченко 2016], Я. Поліщука [Поліщук 2018], М. Штогрин [Штогрин 2016] та ін.), проте вихід у світ у 2017 році роману «Інтернат» змушує по-новому подивитись на цю проблему та й 
на самого автора, який уже не «Вічний Підліток», який обрав, «бездомність», «безбатьківство», дорогу, «яка нікуди не веде» [Гундорова 2013: 160] та про покоління якого Тамара Гундорова писала: «Топографія міжчасся - ось час, у якому перебувають дев’ятдесятники. Їхній простір - станції відправлення та прибуття, їхні родичі - мандрівники, тобто особлива каста людей, бездомних і не вкорінених, яких, власне, й зріднює їхня бездомність» [Гундорова 2012: 205-206].

Отож метою цієї статті є аналіз різних проекцій топосу Дому в романі Сергія Жадана «Інтернат» крізь призму мотиву (без)домності як свідомої відмови, примусової втрати, віднайдення та повернення Дому.

\section{Дім як мікрокосм/Внутрішній Дім}

Трактування Дому як власного мікрокосму та особливого простору свободи та безпеки є традиційним та універсальним. Окрім фізичного оприявлення домуоселі як матеріально-предметного образу (конкретна локація, особливості елементів архітектури, традиційні (а часом і сакральні) місця дому тощо), в розумінні Внутрішнього Дому важливішим є його особистісне від-чуття чи навіть від-чування. Уже на першій сторінці головний герой роману згадує про свій дім:

Паша любив ией будинок, жив тут иіле своє життя, збирався жити далі. Його побудували німецькі полонені, відразу після війни. Була це доволі простора будівля на дві родини. Друга вуличя від залізничної станиії, густозаселений приватний сектор, в якому жили переважно станиійні робітники. Все їхнє селище й будувалося довкола станції: вона давала роботу, вона ж давала й надію, подібна на чорне від паровозного диму серие, щзо прокачує кров довколишніх балок і лісосмуг. Навіть тепер, коли депо стояло порожне, наче басейн, із якого спустили воду, і в майстернях жили хіба що ластівки та бомжі, життя все одно трималося залізниці [Жадан 2017: 7].

Сергій Жадан не малює ілюзій про «дім-фортецю» чи «дім-мрію», а одразу окреслює локацію - будинок розташований на залізничній станції, на певному символічному роздоріжжі. Автор використовує традиційний мотив дороги, апелюючи до теми прощання 3 рідним домом та можливого (не)повернення (до)Дому. Письменник ще на початку роману через деталі десакралізує дім Паші, де наче вічний вогонь» цілодобово горить телевізор «не так для втіхи живих, як у пам'ять про померлих [там же], де життя пішло із осель із пересушеними від пекучого літа колодязями [там же: 8]. Дім, де жив Паша, схожий на половинку хліба 
на магазинній полиці, бо це дім - на дві родини. У такий спосіб Сергій Жадан апелює до проблеми не-свободи та залежності від Іншого (в цьому випадку сусіда, який після пожежі не захотів відбудовувати свою половину, тому сів на потяг у східному напрямку ци назавжди зник...) [там же: 9]. Автор чітко проводить демаркаційну лінію між людьми, для яких дім - це святиня, а для яких - просто «тисячка цегли». Та й у самого Паші внутрішнє відчуття Дому дещо деформоване. Ароматом Дому для нього є не запах свіжоспеченого хліба чи меду, який щойно зібрав дід із пасіки, а

солодкавий запах газу»: «Цей запах супроводжує його все життя, у нього навіть апетиту немає, коли випадає прокидатись не вдома, бракує домашньої ранкової плити, щэо відгонить пропаленими конфорками [там же: 13].

Однак, неодноразово переживши «межову ситуацію» на шляху повернення Санька з інтернату, у свідомості головного героя поступово відбуваються зміни: дім перестає асоціюватись виключно 3 побутовими деталями чи відчуттям комфорту, а перетворюється на місце самості, самоусвідомлення, зв'язку із предками, зрештою, і на місце любові, яку Паша втратив.

Сергій Жадан уміло змальовує моменти із сакральним елементом будь-якого дому - криницею, яка від засохлої, нежиттєдайної водойми, яку ніхто не чистить і не доглядає, перетворюється на тотем:

Перед ними - колодязь. Колодязь дбайливо обкутано ковдрами та старими куфайками: щуоб нічого не потрапило всередину [там же: 139].

Автор веде героїв назад (до)Дому. Вони намагаються змінити ситуацію, виправити помилки та навести лад, адже бояться втратити Дім, бояться забути його запах:

Світ простий $і$ зрозумілий. Його рівно стільки, скільки ти зможеш відчути й охопити своєю пам'яттю. Він має чіткі обриси й мічні кордони. Кордони ияі пролягають зовсім поруч -за ближчим рядом дерев. Там, далі, за ичими видимими кордонами, починається щзось інше - щэось иілком чуже, незрозуміле й тому малоиікаве... Тут натомість - усе на своєму місиі, все можна пізнати на дотик, усе відчитується за голосом. Дім, наповнений тисячею предметів, місткий $і$ вивчений напам'ять...Родина, до якої звик так, як звикають до власного тіла. Батьки - ще живі й здорові...Для ворогів теж місия вистачить...Усьому стане місия...Головне - не виходь поза кордони... [там же: 226-227]. 
Апелюючи до П’єра Нора, Дім можна означити як місце пам'яті [Павличко 1999: 101], як ту значущу одиницю, яка $є$ символічним голосом предків, тому важливо не втратити пам'ять дому, щоб не відчути «запаху безпорадності». Це

...запах, новий, незвичний. Запах чужого...запах цей зовсім інакший...в ньому, крім утоми та байдужості, проступає щзось загрозливе... [Жадан 2017: 125126].

Внутрішній Дім здатен виконувати й терапевтичну місію. Саме він допоможе забути героям увесь жах війни, полікує та заспокоїть, замкне на своєму горищі травмовану пам'ять:

Тому найкраще - вибратися звідси, знайти таксі, пойхати додому, забути це все і не згадувати. Можна все ие забути? - запитує Паша сам себе. Звісно, щчо можна, відповідає він сам собі. Звісно, щуо так. Я про все забуду, переконує себе Паша, і малий теж забуде. Не треба йому всього изого пам'ятати, ні до чого йому ией запах сірки й сирого людського м'яса, не варто йому згадувати цей бруд під нігтями. Людина не має тримати в пам'яті стільки страху й злості. Як із циим потім жити? Він усе забуде, з ним усе буде добре, він забуде про інтернат, про сирітство, про відчуття замкнутості з яким прокидаєшся у чорному підвалі. Хай краще згадує щуось хороше, щзось, щчо не викликає ненависті та відчаю. Запах дому, або запах дерев на подвір $і ̈$, або запах відлиги - січневої, тривалої, щэо пахне рікою [там же: 307].

Дім дарує надію, таку необхідну, як повітря та вода. Він вчить відпускати травмоване минуле:

Завтра все буде інакше, завтра все буде, як завжди, буде, як раніше: розмірені дні, вдома, де кожен займається свойм, де все на свойх місиях, де немає нічого зайвого й нічого непотрібного. Ранки, наповнені хатніми клопотами, робота, до якої звикаєш, як до одягу: не тисне, не заважає, носиться, доки носиться. Тихі вечори, темні ночі. Стільки в усьому цььому, виявляється, втіхи, стільки тепла. Варто було потрапити сюди, в середину пекла, аби відчути, як багато ти мав $і$ як багато втратив. Просто потрібно швидше повернутися додому, облишити нарешті цуе ходіння колами чужої біди, швидие додому, швидие [там же: 308].

Сергій Жадан вдало вибирає обрамлення роману - дорога героя починається та закінчується Домом, який став вихідною точкою на шляху до переродження Паші та місцем, куди герой повертається вже іншим. Владімір Топоров у дослідженні «Простір та час» зазначає, що дорога завжди веде до омріяного центру, при цьому «виступає не тільки у формі зримої реальної дороги, але і метафорично - як позначення лінії поведінки (особливо часто моральної, духовної)...метою є не завершення шляху, а сам шлях, входження на нього, приведення свого Я, свого 
життя у відповідність зі шляхом, із його внутрішньою структурою, логікою та ритмом» [Топоров 1983: 268]. У свідомості головного героя відбулися кардинальні зміни щодо розуміння поняття «внутрішній дім», що часто є синонімом до слів «сім'я», «родина»: «Дім - це місце, де в основному розгортається і тілесне, i душевне, і духовне життя сім'ї, дім має свій простір і свій об'єм, свої запахи, своє обличчя, свої голоси» [Ничипоров 1994]. Паша переріс у Павла, подорослішав, відчув зв’язок із своїм племінником, відповідальність за нього. Апелюючи до Емануеля Левінаса, категорію простору в романі можна трактувати i як усвідомлення себе у світі й вагомості в ньому Іншого. Зрештою подібні процеси відбулися із Саньком:

Паша помічає, як у малого за изі дні змінився голос: говорить спокійно, не поспішаючи. Так, ніби справді йому, Памі, довіряє. Тепер би ще додому його довести ... [Жадан 2017: 296].

Автор наголошує на важливості таких трансформацій, коли дім солодкавого запаху газу для перетворюється у дім, де пахне свіжими простирадлами (саме такими словами закінчується роман: Вдома пахне свіжими простирадлами [там же: 344].

\section{Дім як макрокосм/Великий Дім}

Мотив (без)домності як втрати Батьківщини пов'язаний із образом Великого Дому, Дому як макрокосму. У романі «Інтернат» Сергій Жадан торкається надзвичайно болісної теми - сучасна російсько-українська війна та як наслідок втрата Україною частини своєї території.

Трагедія вимушеної (без)домності - один з основних мотивів твору. Автор досить обережно, проте ретельно описує процеси, пов'язані із втратою своєї землі, свого макрокосму, де ти відчував себе вільним та захищеним. Письменник намагається «копнути глибше», щоб пояснити причини безпритульності сьогодення. По-перше, Сергій Жадан акцентує на відсутності бажання значної кількості українців бути причетними до Великого Дому. Вони живуть виключно у своєму мікросвіті. Так, головний герой Паша всіляко відмежовується від загальнодержавних проблем, намагається втекти і закритися у своїй хаті із запахом солодкавого газу: 
Старий спить у кріслі, з екрана до нього намагається докричатися хтось, залитий кров'ю, але марно: звук старий вимкнув ще з ночі, його тепер не дістанеш, хоч як кричи. Паша на якусь мить затримується, дивиться на кров. Той, що кричить, теж переводить погляд на Пашу та кричить уже до нього: не вимикай, послухай, це важливо, тебе ие теж стосується. Але Паша швидко знаходить пульт, витискає, ніби пасту з тюбика, велику червону кнопку, кидає пульт на стіл і виходить надвір, обережно, щуоб не розбудити старого, причиняючи за собою двері. Але двері все одно тривожно поскрипують у ранкових сутінках, старий у кімнаті відразу ж прокидається, знаходить пульт і мовчки вмикає телевізор, в якому відбувається щзось жахливе, щось, що стосується всіх. А Паша вже добігає до станиії [Жадан 2017: 13-14].

Не менш важливою деталлю у романі є ставлення героя до рідної мови, яку за Мартіном Гайдеггером, трактуємо «домом буття». Мова $є$ відображення світоглядної картини як нації, так і особистості. Відтак нехтуванням нею в побутовому житті (Паша як вчитель української мови не вважав за потрібне говорити українською поза школою), вживання русизмів, ідентифікація себе як не «Павло», а «Паша» - все це було «домом буття» внутрішнього мікрокосму героя. Таким чином одну із територій свого Внутрішнього Дому він давно добровільно втратив.

Ярослав Поліщук так коментує вибір С. Жаданом такого типу героя: «Гадаю, вибір такої постаті на головного героя роману - не випадковий: ним автор підкреслює невизначений, несформований, непроявлений тип локальної ідентичності, який репрезентує сьогодні Донбас» [Поліщук 2018: 169]. Письменник за допомогою спогадів героя намагається підвести читача до розуміння такої поведінки Паші, над яким висіла тінь радянського минулого, де батьки не мали часу для дітей та створення того сакрального простору 3 особливою внутрішньою атмосферою дому. Вони - люди совка, які думали про плани та п'ятирічки, а у 90x - про те, як вижити. Це покоління «травмованих безхатьків», яким ніхто не пояснив, що світ небезпечний та складний, але водночас - багатий та прекрасний; що для того, щоб бути щасливим у своєму мікросвіті, ти зобов'язаний бути причетним до життя Великого Дому, тому

...вихід поза межі власного кокона, поза межі зрозумілого виявився першою катастрофою, травмою, яка потім супроводжуватиме його протягом довгого часу...за першої-ліпшої нагоди, щэойно з'являється можливість тікає додому...назад у його кокон, назад до його зону комфорту [Жадан 2017: 228]. 
Комплекс бездомів'я та відчуття неминучої втрати Великого Дому (те, що Ярослав Поліщук називає «комплексом безгрунтярства та депресивності» [Поліщук 2018: 171]) постійно переслідували Пашу:

Хоча зрозуміло було, щзо місто здадуть, щчо державні війська змушені будуть відійти, забравши з собою прапори Пашиної країни, і що лінія фронту так чи інакше відсунеться на північ, до станиії, а отже, і смерть стане ближчою на якийсь десяток кілометрів [Жадан 2017: 17].

Однак на останніх сторінках роману Сергій Жадан обігрує цікавий епізод зі шматком вугілля та відбитком папороті на ньому (ця кам'яна порода вважається ледве не тотемом для кожного мешканця Донбасу). Письменник торкається проблеми зв'язку генерацій та тяглости історії. Автор роману апелює до проблеми відповідальності кожного за долю свого Великого Дому та його втрати:

Мільйон. Ми з тобою ще не народились, а їи уже був мільйон років. Ми з тобою здохнемо, а вона далі десь лежатиме собі. Історія, розумієш? Ось оце - історія. А ми з тобою - не історія: сьогодні ми є, завтра нас не буде [там же: 305].

В ім’я рідної землі люди жертвують своїм життям, а перед смертю бажають одного - почути когось із дому, відчути ще хоч раз те інтимне та рідне. Сергій Жадан з’єднує воєдино макро- та мікросвіт героїв: щоб не втратити Великого ДомуУкраїни, вони втрачаю свій Внутрішній Дім, родину, і навіть життя:

Паша нервує, знаходить останній набраний номер, написано «дім», ну ось иее він $і$ є, зважується, думає, що сказати, нічого не надумує, тому просто натискає...Але ніхто не відповідає. I поранений зовсім гасне, заплющує очі, говорить нічого. Лише стискає Паші руку ,стискає, ніби просить: давай ще, вчителю, набирай...Давай, візьми, доки він щзе тут, доки він живий, візьми, доки він може почути, доки не пізно, ну давай [там же: 321-322].

В описі Дому як макрокосму автор використовує песимістичні кольоративи та танатологічні образи:

...дерева побиті снарядами, вздовж узбіччя тягнуться окопи, і сніг, сніг! темно-жовтий, ніби гнилий, ніби помер кілька днів тому й тепер гниє на свіжому повітрі. У деяких місиях жовті плями розлізлися $i$ стали брунатними, у деяких темні згустки проступають тонко, як родимки на шкірі [там же: 270].

Таким чином він підкреслює, що відбулося поступове перетворення Великого Дому на фантом, на Антидім, на «лісовий дім» (чужий, диявольський простір, місце тимчасової смерті, потрапляння до якого рівнозначне подорожі до потойбічного світу)» [Лотман 2000: 314]: 
Паша дивиться на місто й зовсім його не бачить. Бачить лиме чорну яму, над якою, наче повітряні змії, висять великі чорні дими з довгими хвостами. Так, мовби хтось викачує з міста душі. Й душі изі - чорні, гіркі, чіпляються за дерева, пускають коріння в підвали... [Жадан 2017: 115].

Досліджуючи проблему простору Г. Башляр зазначив, що «підвал - це поховане безумство, в ньому замуровані трагедії. Розповіді про підвали - свідки злочинів залишають у пам'яті незабутнє враження...» [Башляр 2004: 36]. Так автор натякає, що Великий Дім на грані переходу у статус не-Дому (Втраченого Дому), чи навіть більше - Антидому:

Біжсть повз жовтий мертвий сніг $і$ посічені дерева, довгою-довгою звивистою дорогою, на якій трапляються то вирвані звідкись дошки, то втоптані в сніг шматки заліза, то просто брудна ганчірки. І щуо далі біжить, то темнішим довкола стає сніг. Аж раптом його не стає зовсім - лише чорний вигорілий трунт між деревами. I дерева теж вигоріли. I все довкола просякнуте димом і вогнем [Жадан 2017: 271].

\section{Не-Дім/Втрачений дім}

Не-Дім - це «тимчасовий і випадковий притулок, часом недружній і такий, що часто спонукає його мешканців до виживання» [Дубровська 2010]. У романі С. Жадана варто говорити про дві локації, що можна означити цим поняттям: у вузькому значенні йдеться про інтернат, у якому перебував племінник головного героя, а у широкому - про частину Донбасу, що тимчасово окупована чи належить до так званої «сірої зони»:

Метафору інтернат доречно поширити на все населення Донбасу, його ментальність, на весь край. Адже ие населення також жило тривалий час у режимі інтернату, умовного сирітства... [Жадан 2017: 182].

Аналізуючи цей простір, варто звернути увагу на кілька моментів. По-перше, територія, над якою висіла тінь совкового минулого, вважалася простором безпеки, хоч байдуже, що

на стінах - старі радянські таблички з ичивільної оборони. Підлогою розкидані протигази, схожі на голови мурахоїдів. Тут тепліше і затишніше» [там же: 119].

Проте цей «затишний безпечний куточок» радше нагадує інфернальний простір, де панує атмосфера розгубленості та дезорієнтації:

I заходить до боксу. Темний сухий підвал, уздовж стін тягнуться труби. Бетонна долівка, бетонна стеля. Навіть після ядерної атаки можна жити. Ось тільки недовго й безрадісно [там же: 121]. 
Совковість залишалась не лише в побуті, але і в головах мешканців інтернату, які живуть ностальгією за «нормальним дитинством» та «нормальною країною» [там же: 154], не ідентифікуючи себе з новим Великим Домом - з Україною:

...Не в той час народились, не в тій крайні. Інша річ - ми. Ось нам є щзо згадати... У нас була справжня країна, нам не треба було боятись [там же: 156].

Проте нове покоління, народжених уже після 1991 року, змушують своїх символічних «батьків» подорослішати та навчитись говорити правду. Так, на прикладі образу Ніни Сергій Жадан деміфологізує тезу про «щасливе дитинство в кожному радянському домі», яке насправді було голодним та холодним:

...я завжди в кросівках ходила. Влітку і взимку. Хтось із сусідів віддав. Тата в мене не було, чим займалася мама - розповідати не буду. Але те, чим вона займалася, грошей їи теж не приносило. І в неї, до речі, тата теж не було. I вона теж усе своє дитинство проходила в чужому одязі. I теж нічого доброго про своє дитинство не згадувала. I про крайну вашу так само. I не боялись ви не тому, що краӥна у вас така чудова була, а тому щзо вас завжди хтось прикривав: як не батьки, то райком комсомолу [там же: 157].

Щодо ширшого тлумачення топосу інтернату - метафоричного зображення Донбасу - варто звернутись до концепції місия/не-місия французького антрополога Марка Оже. Не-місця - це простори, «позбавлені свого сенсу, без призначення...» [див.: Поліщук 2018; Скопина 2013; Augé 2010]. С. Жадан натякає, що саме Донбас став таким не-місием, у якому неможливо освоїтись чи вгрунтуватись. Він перетворився у статичний простір, де індивіди залишаються самотніми та бездомними, а згодом втрачають, чи навіть зрікаються, своєї ідентичності. Перебування в такій локації спричиняє духовну бездомність, що веде героїв до символічного Антидому, образ якого «розширює свої межі аж до поняття руйнування ідентичності. I тут варто говорити про зруйнований душевний ландшафт, котрий перетворюється на травмоландшафт. Потужній деформації піддається пам'ять нації. У пошуках національної ідентичності ліричному герою притаманне глибинне занурення в пам'ять, яка корелює 3 поняттями історії та культури» [Демченко 2016: 215]. Безперечно, невгрунтованність та «дезорієнтація на місцевості», подвійне травмування тоталітарним минулим та мілітарним сьогоднішнім змушують героїв до роздумів та пошуків власної ідентичності, маркерами якої є і топос Дому в різних значеннях та проекціях. Більшість, на жаль, 
досі не обрали свою єдино можливу ідентичність, вони добровільно дезорієнтовані та обирають не Свій Дім як прийнятний простір для існування:

...давно слід було визначитися, з якого ви боку. Звикли все життя ховатися. Звикли, щуо ви ні при чому, щчо за вас завжди хтось усе вирішить, щуо хтось усе порішає...Судити вас за це, звісно, не будуть, але и на вдячну пам'ять нашадків можете не розраховувати [Жадан 2017: 160].

Із проблемою ідентичності пов'язана проблема пам'яті просторів і просторів пам'яті: «Ми живемо за часів, коли спогад як ніколи стає все ще стає предметом суспільної дискусії. До спогаду апелюють із метою зцілення, звинувачення, захисту. Спогад став важливою складовою формування індивідуальної та колективної ідентичності й стає ареною як конфлікту, так і ідентифікації» [Ассман 2012: 24]. Сергій Жадан мозаїчно вибудовує простори, в яких заблукали, простори, що втрачені чи забуті. Тут важливу роль автор відводить матеріальній «пам'яті просторів», а саме опису доріг, залізничних вузлів, мостів, мотелів, кафе тощо, що зберігають пам'ять про минуле:

За липовою алеєю виходять на дитячий садочок... Пахне їдальнею $i$ багатоденною вогкістю...На підлозі протертий до дір килим, рваний у кількох місиях. Горщчики із замерзлими квітами на стінах, чавунні батареї під вікнами фарбовані в білий колір - Паші здається, щуо він повернувся у власне дитинство, від чого йому відразу ж хочеться повіситись [Жадан 2017: 190].

Власне йдеться саме про простір пам'яті, а не місце пам'яті, на розрізненні яких наголошувала Аляйда Асманн: «Простір, по суті, відрізняється від «знайомих місцевостей i країв» тим, що він розвіданий, виміряний, колонізований, анексований, поєднаний у мережу. Натомість місия, де можна йти вглиб «у кожному місці й у кожний момент», усе одно зберігатимуть таємницю» [Ассман 2012: 319].

У контексті дослідження мотиву (без)домності важливе місце займає образ міста. Сергій Жадан змальовує його як не-Дім, а інколи і як Антидім, що перетворюється в місто-привид. Автор окреслює, як війна змінює його аж до не впізнання і не-пізнання:

Паша дивиться на місто й зовсім його не бачить. Бачить лише чорну яму, над якою, наче повітряні змії, висять великі чорні дими з довгими хвостами. Так, мовби хтось викачує з міста душі. Й ці душі - чорні, гіркі, чіпляються за дерева, пускають коріння в підваги, ніяк їх не вирвеш [Жадан 2017: 115]. 
Свого часу Соломія Павличко акцентувала на тому, що місто $є$ не просто простором чи локацією, а «символом певного типу свідомості як автора, так і його героя» [Павличко 1999: 25]. Місто абсолютно десакралізоване та демонічне. Із нього пішло життя, воно позбавлене життєвої енергії та сили. У ньому не залишилось відчуття Дому, і навіть не-Дім витісняється із міських просторів. «Загублені», «вкрадені» чи «подаровані» місця Дому - ось мапа урбаністичного простору роману:

Паша розуміє, щзо там місто, тисячі будинків, тисячі дерев, тисячі нір та підвалів, по яких прямо тепер ховаються тисячі мешканців изього міста. I спробуй їх там знайти - в такому тумані, спробуй вирахувати. Ні дихання не чути, ні сериебиття, нічого. Тільки цеей густий туман, щэо виповнює собою розбиті під ’̈ззди й понівечені каналізащійні люки [Жадан 2017: 134].

Місто в романі репрезентує душевну порожнечу та занепадницький простір. Свій простір трансформується у Чужий. Звичний культурний ландшафт міста зруйновано. С. Жадан на прикладі різних локальних об’єктів іронічно обігрує мотиви безнадії та песимізму:

... «форд», залимаючи глибокі, мов надрізи, колії в жовтому снігу, підкочується до мотельного паркінгу...Двоповерхове приміщення, над головним входом вивіска «Парадіс»...- «Парадіз», - говорить, посміхаючись. - Швидше перше коло пекла [там же: 30].

Відчуття страху, безвиході та нестабільності автор передає через змалювання екзистенційних картин втраченого дому:

Приміщення невелике, напхалося їх сюди близько двох десятків, сидять під стінами, підпираючи одне одного. Теж переважно жінки та діти...Збоку стоїт туристична гасова грілка, пакет х їжею. Але кожен при бочі тримає i щуось своє, домашнє. Одягнені тепло, до того ж накриваються ковдрами, килимами, пальтами. Скільки сидять - незрозуміло. Але судячи з тяжкого духу й червоних очнииь - не першу добу [там же: 106-107].

Світ рідного/свого стає ворожим:

Паша розглядається розбитим помешканням. У кухні над столом - календар за минулий рік, у великій кімнаті, де вони сидять і гріються, зі стін звисають вигорілі шпалери...Коло ліжка розірвані подушки, кілька штук, маленькі. Очевидно, на ліжку спали діти ... тут иүіле життя вивернуте, мов кишені [там же: 265].

Окремої уваги заслуговує і топос вокзалу. Алла Демченко, досліджуючи збірку Сергія Жадана «Життя Марії», зазначила, що топос вокзалу у творчості письменника «проектується на образ не-дому», а «мотив втраченого дому 
переростає у більш масштабніший мотив втраченого раю, втраченої Батьківщини». Аналогічні проекції спостерігаємо і в романі «Інтернат»:

I тут Паша розуміє, щзо вокзал насправді забитий народом, щзо вони там сидять усередині, немов у церкві в обложеному місті, думають, щчо там їх не дістануть, дивляться крізь вікна на світ, який безупинно звужується [там же: 61].

Автор приписує топосу вокзалу інших конотацій - це не тільки простір, із якого починається пошук себе чи початок шляху до-себе, а простір екзистенційного вибору - прямувати на Схід чи на Захід, чи залишатись на своїй території.

Варто звернути увагу, що в романі Сергія Жадана чи не вперше в українській літературі з'являється новий топос - блокпост. Цей простір теж можна означити як не-Дім, тимчасовий штучний простір пере-бування:

На розвилці й униз, перед мостом, стоять покинуті блокпости, мов розорені кимось пташині гнізда. Домашній одяг, посуд, газети, розбиті армійські коробки, розтерзані вітром мішки з піском - усе це по-сирітськи лежить просто неба... [там же: 52-53].

Ідея (без)домності проектується у Жадана і в іншому контексті - свідома бездомність, бездомність як вибір та жертва. Так, на прикладі образу Пітера письменник акцентує увагу на проблемі «межової ситуації» та екзистенційного вибору. Герой відмовляється як від рідного Дому (родини, роботи), так від Великого Дому (покидає рідну країну, щоб стати добровольцем у російськоукраїнській війні). Проте він знаходить «інший простір», «місце, де сконцентрована життєва енергія», своєрідну гетеротопію (термін, що ввів Мішель Фуко на означення «реальних, дійсних місць, що стосуються інституційної сфери суспільства, що в той же час $є$ контрмісцями, фактично здійсненими утопіями» [Фуко 2006]).

\section{Дім як В'язниця/Антидім}

У книзі «Гібридна топографія. Місця й не-місця в сучасній українській літературі» Ярослав Поліщук зазначає: «Метафора інтернату окреслює той кризовий і роздвоєний стан, у якому - ніби тимчасово, але надовго, імовірно, на все життя - зависають персонажі твору...можна сприймати образ інтернату принаймні в кількох значеннях. Насамперед - як психологічний комплекс, задавлену образу, ресентимент. Виховані в інтернаті, позбавлені батьківської опіки й справжнього 
тепла, «казенні» діти великої країни стають назавжди заручниками свого виховання. Вони звикли до сирітства й ущербності, тому й у дорослому житті уникають відповідальності, поводяться неадекватно та інфантильно» [Поліщук 2018: 181]. Відтак лише внутрішнє переродження та переусвідомлення себе можуть допомогти героям вибратися 3 Антидому, покинути зону бездомів'я та безбатьківства, перебороти депресію та перехитрити смерть:

...йому будь-ще треба тікати, треба бігти подалі від ицих крапок на сірому тлі, бо ие рухається його смерть, $і$ в жодному разі не можна дати їй себе наздогнати. Це все, що необхідно: не дати себе наздогнати, спробувати вирватись з иьього сірого глибокого місива, дістатись додому, спробувати перехитрити власну смерть [Жадан 2017: 289-290].

Варто зазначити, що мотив (без)домності та перехід у зону Антидому проектується у трьох площинах: втрата Дому як вибір, як кара та як відсутність вибору.

Свідому відмову від свого Дому (як макро- і мікросвіту) репрезентує епізод зустрічі Паші та його колишнього учня, який прийняв днр-івську ідентичність як єдино можливу, який простір Антитому ідентифікує як Свій простір:

Як же так сталось? Як я не помітив, що мої учні тепер воюють проти мене? Як я це пропустив? Хоча, пробує він себе заспокоїти ,чому проти мене? Не проти мене? До чого тут я? Та ладно, не проти тебе, тут-таки не погоджується він із собою, зрозуміло ж, шо саме проти тебе, конкретно проти тебе. Проти всього того, щзо з тобою пов'язане [там же: 254].

Друга проекція - втрата Дому як кара реалізується через образи більшості героїв роману. Це і фізрук, і Віра, і ще сотні інших жителів Донбасу, які, на думку Жадана, як і Паша, нічого не зробили для збереження власного Великого Дому:

Краӥна стрімко змінилась, а ось вони всі - ї̈ громадяни, мешканці окремо взятого залізничного вузла - змінитися не змогли, не було в них закладено таких механізмів [там же: 208].

Зосереджується автор і на проблемі відсутності вибору, наслідком чого стало примусове перебування в зоні Антидому:

Де ї дім? Коли вона туди потрапить? Половина з них не має домів: розбрелися довколишніми містами, вибралися звідси безкінечними вагонами, розгубилися світом. Скільки часу тепер необхідно, аби вони повернулися? А коли повернуться - чи впізнають свої доми? Адже раніше все ие мало зовсім інший вигляд. Нині тут важко щуось упізнати: помешкання без голосів, вулиці без світла, площуі без птахів [там же: 125]. 
Власне ці люди не втратили поклику дому, що лунає всередині них (Гастон Башляр). Збережене внутрішнє відчуття допомагає перетнути кордон Чужого простору i повернутись у Свій. Мотив трагічної дороги від дому (втраченого/забутого) до Дому (віднайденого/переусвідомленого) можна розглядати як кінець екзистенційної безпритульності героїв (М. Гайдеггер).

Дім - це носій пам’яті та генератор спогадів. За Гастоном Башляром, «крипта рідного дому...це вісь, навколо якої обертаються інтерпретації мрії думкою та, навпаки, інтерпретація думки мрією... Перед нами нерозривна єдність образу і спогадів, функціональна суміш уяви й пам’яті» [Башляр 2004: 35]. Ці спогади часто пов'язані з символічними образами, зокрема, в аналізованому романі з образом снігу, що вкривав рідне місто та оселю:

Слухав, як мама торохтить посудом на кухні, як старий виходить надвір, щуось забрати з подвір'я, як потому вертається, і свіжий дух синього нічного снігу перетікає помешканням, торкається шкіри, і враз відчуваєш усю цю зиму, відчуваєш, як їі багато, як вона починається ось тут, за вікном, між цих дерев, як заповнює собою весь довколишній простір: їхнє засніжене подвір'я, вулицю із сонними будинками, з яких до неба підіймаються дими, дорогу, яку зранку доведеться чистити, місток, так само заметений нічним снігом, крамниці ц̆ бібліотеку, школу, контори, станційні приміщення, будівлю вокзалу, порожню о иіій годині - весь той шлях, яким він може пройти наосліп, до якого він звик із дитинства, який у нього з дитинством і асоиіюється...i перед ним відкривається иілий світ - по віния снігом... [Жадан 2017: 286-287].

Отже, мотив (без)домності в романі Сергія Жадана реалізується через різні проекції топосу Дому. Трактуючи Дім як філософсько-онтологічну константу, автор звертається до проблеми внутрішньої бездомності, екзистенційного сирітства та свідомої невгрунтованості. Аналізуючи травмоландшафт Донбасу, письменник ретельно вибудовує шлях до Дому як єдино можливий варіант повернення внутрішньої цілісності героїв, як можливість усвідомлення своєї ролі у макросвіті Великого Дому та шанс попрощатися із інтернатом як символічним простором внутрішньої колонії.

\section{ЛIТЕРАТУРА}

Ассман, А. Простори спогаду. Форми трансформації культурної пам’яті, Київ 2012. Башляр, Г. Избранное: Поэтика пространства, Москва 2004.

Гриценко, Є. Інтерв'ю. Сергій Жадан: «Поетичними є всі характери, варто лише спробувати їх відчути та зрозуміти». URL: http://interviewer.com.ua/culture/serhiy_zhadan/ (17.08.2018). 
Гундорова, Т. Післячорнобильська бібліотека. Український літературний постмодернізм. Київ 2013.

Гундорова, Т. Транзитна культура. Симптоми постколоніальної травми: есеї. Київ 2012.

Демченко, А. Поетика тріади «дім - не-дім - антидім» у збіриі Сергія Жадана «Життя Марії», в: Сучасні літературознавчі студії. Феномен дому в літературознавчій перспективі: збірник наукових праць, гол. ред. Н. О. Висоцька, Київ 2016, вип. 13, с. 207-216.

Дубровська, А. Опозииія «Дім»/ «Антидім»у романі В. Винниченка «Хочу!», «Вісник Луганського національного університету імені Тараса Шевченка», 2010, №4 (191), с. 135-143.

Жадан, С. Інтернат. Чернівці 2017.

Кочерга, С. Архетипні мотиви дому і бездомів’я в творчості Лесі Українки, „Studia Methodologica", 2008, вип. 25, с. 115-120.

Лотман, Ю. Семиосфера: Культура и взрыв. Внутри мыслящих миров. Статьи. Исследования. Заметки, Санкт-Петербург 2000.

Ничипоров, Б. Введение в христианскую психологию: Размышления священникапсихолога. Москва 1994, URL: https://azbyka.ru/otechnik/antropologiyaiasketika/wvedenie-v-hristianskuyurpsi hologiyu/(17.08.2018).

Нора, П. Теперішнє, нація, пам'ять, Київ 2014.

Павличко, С. Дискурс модернізму в українській літературі. Київ 1999.

Поліщук, Я. Гібридна топографія. місця й не-місця в сучасній українській літературі. Чернівці 2018.

Скопина, М. Феномен «места» $и$ «не-места» в постиндустриальном городе. «Вестник МГСУ», 2013, № 1, с. 66-71. URL: https://cyberleninka.ru/article/v/fenomen-mestai-ne-mesta-v-postindustrial nomgorode-1 (2.09.2018).

Топоров, В. Пространство и текст // Текст: семантика и структура, Москва 1983.

Фуко, М. Другие пространства (конференция) // Интеллектуалы и власть: Избранные политические статьи, выступления и интервью, ч. 3, Москва 2006, с. 191204.

Штогрин, М. Місто як спогад у романі Сергія Жадана «Ворошиловград», «Наукові записки Національного університету „Острозька академія”. Серія Філологічна» 2016, вип. 62, с. 361-363.

Элиаде, М. Космос и история. Избр. Работы, Москва 1987.

Augé, M. Nie-miejsce. Wprowadzenie do antropologii hipernowoczesności, Warszawa 2010. 